\title{
Renewing stigmatised estates in the Netherlands: A framework for image renewal strategies
}

\author{
FRANK WASSENBERG \\ OTB Research Institute for Housing, Urban and Mobility Studies, Delft University of \\ Technology, P.O. Box 5030, 2600 GA Delft, The Netherlands (Tel.: + 31-15-2784461; \\ Fax:+31-15-278-3450; E-mail: wassenberg@otb.tudelft.nl)
}

\begin{abstract}
Like in so many other European countries, the large housing estates of the post-World War II generation in the Netherlands did not fulfil the great and often Utopian expectations. Nowadays they are confronted with the effects of a negative image, a stigma. Images differ according to the persons asked for an opinion. Internal images, elicited from insiders, may overlap with external images but may also contradict them. The external image of many large estates accelerates their decay and lowers their reputation. All across Europe stigmatised large housing estates are subject to major renewal processes. The Amsterdam high-rise area of the Bijlmermeer is a good example. Once cheered by planners and politicians, later on criticised by inhabitants, avoided by outsiders and stigmatised by the media, the area is now an example of an impressive renewal programme. The question arises whether urban renewal will change a negative reputation. A stigma tends to stick, even after actual renewal activities are finished. Images of neighbourhoods can actively be promoted, just like a commercial product. Image promotion can be a supplementary strategy, which is seldom used in renewal processes. Which strategy would be the best depends on local circumstances, but strategies should be aimed at improving existing internal and external images. Image promotion may be directed to internal participants, to convince them the situation really is improving, or to outsiders, to promote the area and to counterbalance prejudices. Image promotion should not take the place of real improvements, but it is useful to work on a stigma and to give active image promotion explicit attention in any renewal process.
\end{abstract}

Key words: image, large housing estates, reputation, the Netherlands, urban renewal

\section{Introduction}

This paper discusses the relation between images of estates and their approaches to renewal. It starts from the observation that many large housing estates are coping with an unforeseen negative image, a stigma, and goes into the factors that determine such an image. The paper 
elaborates on the differentiation between the images held by internal and external participants. Stigmatised problematic areas, among them many large-scale housing estates, are being renewed in the Netherlands, like elsewhere in Europe. The question is raised whether urban renewal approaches will change a stigma. A second question in this paper concerns the possibilities to improve a stigma and about the strategies that can be used. This article underlines the active use of image-building strategies as a complementary part of an urban renewal process. Moreover, the article provides an analytical framework to be able to differentiate between strategies according to the experienced internal and external image. Especially when the internal and the external image of a particular neighbourhood differ from each other, image-promoting activities can be useful. The article goes into the various possibilities for renewing the image of the distinguished areas and elaborates on situations where internal or external image promotion can be more successful. These possibilities are illustrated with the negative image of the Bijlmermeer high-rise estate in Amsterdam, where a large renewal programme is taking place. It is shown that in this case image renewal concentrates on the internal participants.

\section{The remarkable image of large housing estates}

Debates about large housing estates in the Netherlands are, as in many other European countries, about housing built in the 1950s, 1960s and early 1970s. During this period, housing was characterised by chronic shortages, and political priority was given to housing production. Nevertheless, it lasted until the 1950s before large amounts of housing were produced. In the 1960 s new techniques became available to increase the housing production by building higher in a shorter time at lower costs (Turkington et al., 2004). During the 1960s, the construction of high-rise flats predominated in many cities in Europe, culminating in a high-rise boom that in most Western countries lasted for no more than 10 years. After the high-rise wave a countermovement started in the Netherlands, as in many other countries, with the emphasis on building single-family houses in small-scale developments, on curved streets and 'back to the human scale'. Large housing estates dominate the post-war developments. About $40 \%$ of the total housing stock in the Netherlands was built in the period 1945-1975. Peak production was achieved in 1972 and 1973, with over 150,000 houses a year. That is twice the present volume of housing production. 
Neighbourhoods from the 1950s are a mix of low-rise blocks of flats and single-family dwellings, most of them in the rental sector. They are characterised by half-open blocks of buildings, arranged in a fixed pattern with a communal courtyard. The urban design was strongly influenced by the CIAM movement, "Congrès Internationaux d'Architecture Moderne", the international movement for modern building. They organised a series of conferences between 1928 and 1959, that were of great influence on urban planning in post-war decades, with much attention to light, air and space. Neighbourhoods from the 1960s and early 1970s were still a mix of housing types. Although high-rise dominated visibly many new developments, the majority of the new housing was single-family houses. Most urban neighbourhoods still were a mix of housing types, among them high-rise blocks. The ideology of these neighbourhoods still consisted for a major part of the CIAM ideas. Notions of rational, efficient, healthy and functional building found their way into many large-scale neighbourhoods. With the ideas of the 1930s and the techniques of the 1960s, many new areas were developed. These were to be modern alternatives for the stuffy and narrow tenements in the inner cities.

Many of the large housing areas were very well thought of when they were built. This is especially true of the high-rise estates of the late 1960s and early 1970s. Plans from those days contain well-founded ideas about how people should live, about privacy, optimal position for sunshine, separation of traffic flows, and large greens with common uses. An influential report of the Dutch government of those days describes the advantages of high-rise living as follows: High-rise living offers opportunities for privacy as much as possible, together with a maximal perception of visual contact with nature, space and society, making it outstanding for the people of tomorrow (Commissie Hoogbouw-Laagbouw, 1961).

Because of the very tight housing market of that time, all new housing was welcome. Qualitative remarks were rarely made, and if so, nobody listened. The Amsterdam Bijlmermeer is a good illustration of the way new areas were developed in the 1960s (see the case). Mentzel (1990) gives an overview of the realisation of this large high-rise area, an example that urban planners all over the world should take to heart. What has gone wrong since then and what drastic measures are being taken in the Bijlmermeer at this moment are some of the issues addressed by Helleman and Wassenberg (2004).

In later years, when opportunities became available, many large-scale neighbourhoods of the post-war decades lost their favoured position on 
the housing market they had occupied in the early years. Gradually, satisfaction made place for complaints about the house, the neighbours and the surroundings; the once long waiting lists were replaced by refusals and vacancies and, important in this discussion, the reputation gradually changed.

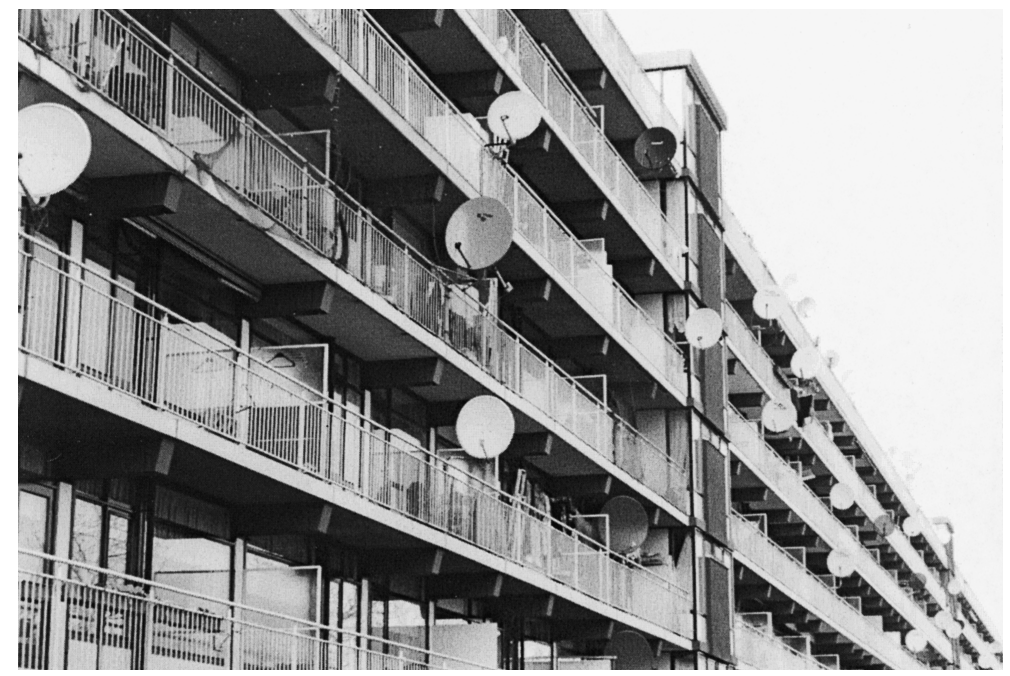

Photo 1. From the outside it is obvious that many immigrants live here (photo: F. Wassenberg).

\section{Internal and external image creation}

People within and outside an area form images of that area; these are called internal and external images. The participants can be divided according to the interest they have. Three groups of actors can be distinguished that may value a neighbourhood: inhabitants, the local government and other parties concerned, like shopkeepers or house owners (Nelissen, 1976, p. 13). Literature about images of neighbourhoods is often based on surveys about the satisfaction of the inhabitants (Hortulanus, 1999). The more satisfied people are with how they live, the higher their appreciation and the higher their internal image will be. All other parties not bound to the area form external images. Hortulanus states, in a description of reputation theories, that an important characteristic of external image creation theories is that neighbourhoods are compared with each other. Whereas inhabitants look at satisfaction and a good dwelling, external actors define neighbourhoods in relation to each other and give them a place in the local neighbourhood hierarchy 
(Hortulanus, 1995, p. 42). These comparisons make use of ordinary but recognisable names: a working-class district, a slum, a middle-class area, and the gold coast. Neighbourhoods are associated with status. The local 'high-rise district' is labelled too, and it is given a position in the personal housing hierarchy. By giving areas names, external participants get an image of that neighbourhood, perhaps without knowing the area itself. It is important to note that images and stigmas are connected to the physical appearance of an area. Both the appearance (housing types, layout) and the name can stigmatise a neighbourhood.

\subsection{The role of the media}

External images are both shaped and initiated by the media: press, television, radio, music, and so on. Unless a journalist is living in the area, something that hardly ever happens, media images are externally set. As the lines in the newspaper and the minutes on television are scarce, journalists have to be short; they opt for stereotypes and leave out the nuances that scientists are used to making. A stereotype, once set, is hard to change.

The way the media can confirm, set or change images should not be underestimated. The Amsterdam high-rise area Bijlmermeer is probably the most stigmatised area in the Netherlands (see Section 7). Nauta et al. (2001) conducted a survey on the way the Bijlmermeer was covered in the newspapers in the period 1995-2000. They counted all articles in three main papers (Volkskrant, Parool and Algemeen Dagblad) that were written about the Bijlmermeer neighbourhood.

The amount of articles about the Bijlmermeer area has risen over time, with a strong dip in 1999. Figures 1 and 2 show the results of the review of press coverage. After a dip in 1997, the amount of coverage of crime, safety and nuisance rose substantially. Over one-third of all articles were about these negative items. Attention for social items (about people, employment, schooling) gradually dropped after a peak in 1997. In 1995, the first urban renewal of the Bijlmermeer was visible: demolition, refurbishment, new low-rise developments. These got much attention. After that year, the press coverage of urban renewal activities dropped down gradually to a stable level of about $20 \%$ of all articles written about the Bijlmermeer.

The judgement in the articles fluctuated but slowly improved after the first years under review (1995-1997). During these years, over half of all 


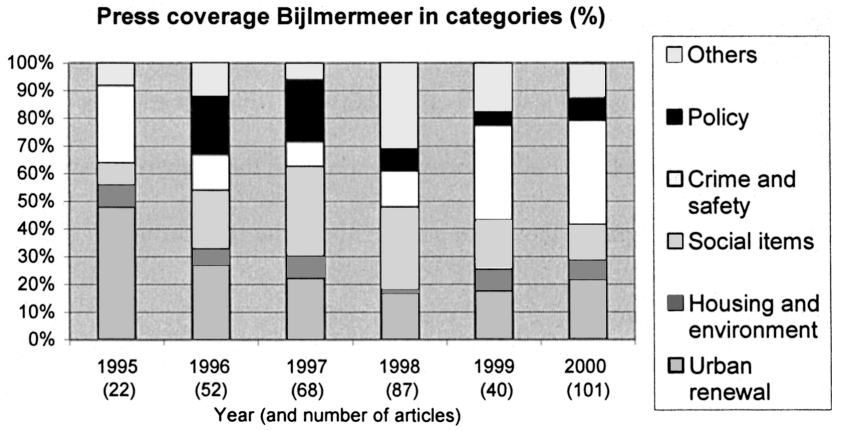

Figure 1. Press coverage Bijlmermeer in categories (\%). Source: Nauta et al. (2001), author's calculation.

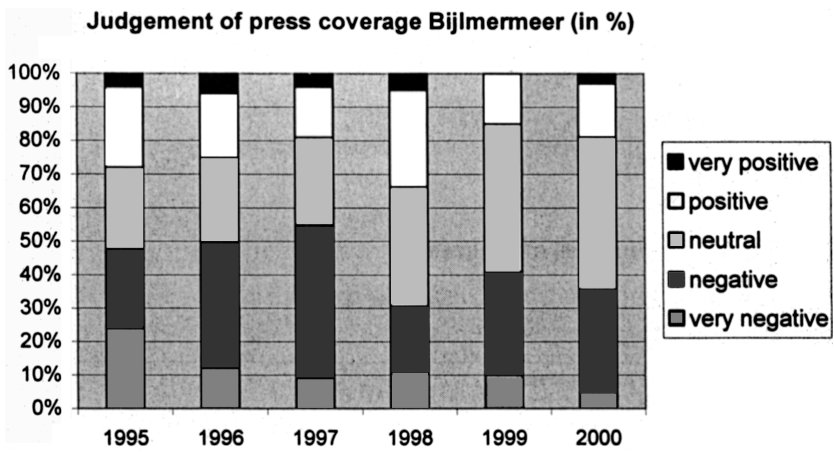

Figure 2. Judgement of press coverage Bijlmermeer (\%). Source: Nauta et al. (2001), author's calculation.

articles were (very) negative, while this decreased to about one-third during the last 3 years (1998-2000). During the last years, more articles were neutral in tone. Interestingly, the most positive articles were the longest, while negative articles, especially those about crime, were shorter.

A conclusion we might draw from the press coverage survey is that image-building about the Bijlmermeer area became slightly less negative.

\subsection{Internal and external participants}

Dean and Hastings (2000) distinguish six groups of inhabitants: residents, leavers and incomers, and each of these three groups divided into those with a positive or a negative view. The survey covered three 
stigmatised large-scale neighbourhoods that were being redeveloped. While they only looked at the inhabitants, other parties are involved too, and the latter form their own image of the estate. In Table 1 we have extended these six categories and put together a range of participants that may form an image of an area, both internal and external, both inhabitants and others. In the table we mention some specific features that are characteristic of these groups. We are aware that this list is not complete. The first six features are according to Dean and

Table 1. Participants and their images of an area

\begin{tabular}{|c|c|c|}
\hline Participant & $\begin{array}{l}\text { Internal } \\
\text { or } \\
\text { external }\end{array}$ & Some characteristics \\
\hline Committed residents & Internal & $\begin{array}{l}\text { Choose to stay, positive self-image, blame the } \\
\text { media for the unjust stigma, blame the council } \\
\text { for neglect }\end{array}$ \\
\hline Budding incomers & External & $\begin{array}{l}\text { Rather positive about the estate, often lived } \\
\text { here before, blame media for the unjust } \\
\text { stigma. May come soon }\end{array}$ \\
\hline Potential leavers & Internal & $\begin{array}{l}\text { Differentiate between parts of the estate, } \\
\text { uncertain future }\end{array}$ \\
\hline Doubtful incomers & External & $\begin{array}{l}\text { Differentiate between parts of the estate, } \\
\text { uncertain future }\end{array}$ \\
\hline Probable leavers & Internal & $\begin{array}{l}\text { Overall negative image of the estate, blame } \\
\text { council neglect and people. Want to leave }\end{array}$ \\
\hline Improbable incomers & External & $\begin{array}{l}\text { Negative image of the whole estate, blame } \\
\text { residents' own behaviour. Surely will not } \\
\text { come }\end{array}$ \\
\hline Media, journalists & External & $\begin{array}{l}\text { Looking for news, exaggerating facts, most } \\
\text { influential external image builders, } \\
\text { stereotyping stigmas }\end{array}$ \\
\hline Politicians & External & Diverse, image influenced by public opinion \\
\hline Civil servants & External & Serving the 'general interest' \\
\hline Police & External & Confronted with the problems \\
\hline $\begin{array}{l}\text { Public housing } \\
\text { association }\end{array}$ & External & A main concern is the rentability of the estate \\
\hline Public housing employees & $\begin{array}{l}\text { Internal/ } \\
\text { external }\end{array}$ & $\begin{array}{l}\text { Confronted with results of bad image } \\
\text { (removals, refusals, maintenance costs) }\end{array}$ \\
\hline Market parties, Investors & External & Counting risks, hesitant to invest in bad areas \\
\hline
\end{tabular}


Hastings' division and the characteristics they attribute to them. In fact, these first six apply to the inhabitants - as those Dean and Hastings refer to - but also to shopkeepers, house buyers, investors, etc.

\section{A framework for neighbourhood images}

Both internal and external participants can have a positive or a negative feeling about a particular neighbourhood. Their image can be good or bad. This can be depicted in a diagram in which the participants are at the borders (in the column and row headings) and the several neighbourhoods can be placed in the matrix (in cells), according to their experienced internal and external images. Table 2 shows schematically the four categories any specific neighbourhood can be positioned in.

A neighbourhood that is positioned in the left upper corner (1) is acceptable. When both the internal and external image are good, the area will be a pleasant neighbourhood where things are going well and few problems exist. A position in corner (2) is worse: The internal image is reasonable, but the external image is not good. Neighbourhoods positioned in this corner are often isolated and unknown areas, and non-residents do not see any reason to move there. Sometimes large housing estates have been built on abandoned sites, often for financial reasons (cheap land, easy building methods). Committed residents complain about the stereotyping in the media, especially by journalists who hardly know the area. If external participants were to come there, they would probably will be content, but unfortunately they do not know the area.

Corner (3) is not satisfactory either, but for different reasons. The external image is reasonable, but the internal image is not. Often there

Table 2. Neighbourhoods situated according to internal and external images

\begin{tabular}{lll}
\hline \multicolumn{2}{l}{ Image } & \multicolumn{2}{c}{ External image } & \multicolumn{1}{l}{ Bad } \\
\cline { 2 - 3 } & Good & (2) Unknown qualified neighbourhoods \\
$\begin{array}{l}\text { Internal Good } \\
\text { image }\end{array}$ & (1) Nice neighbourhoods & (3) Unsatisfactory \\
& neighbourhoods & (4) Problematic neighbourhoods \\
\hline
\end{tabular}


are many problems that deal with liveability in the surroundings, like pollution, crime, noise, traffic congestion, neighbourhood quarrels, etc. Houses may look attractive at a first glance, but the inhabitants complain about the poor quality, their size and their noise; similarly, they complain about the liveability problems in the direct surroundings. Generally speaking, the area is bad according to the experience of the insiders, but external participants judge it without first-hand experience. If they were actually to go there, they would be confronted with the same kinds of problems that the internal participants face at present. Actually, this means once the outsiders become insiders, their experienced image would decline. Examples of neighbourhoods in this corner can be found just outside the city centres in areas with older housing stock.

Neighbourhoods in corner (4) are in the worst position. The image held by both internal and external participants is bad. The number of committed residents is low, budding incomers are few, complainers about all kinds of things are numerous. Moreover, professional external parties are consistent in their negative view. It depends on the overall housing market whether there are many vacancies or if it is scarcity that fills up even the worst housing estates, obviously not with people who would prefer to live there. The most problematic housing estates are positioned in this corner.

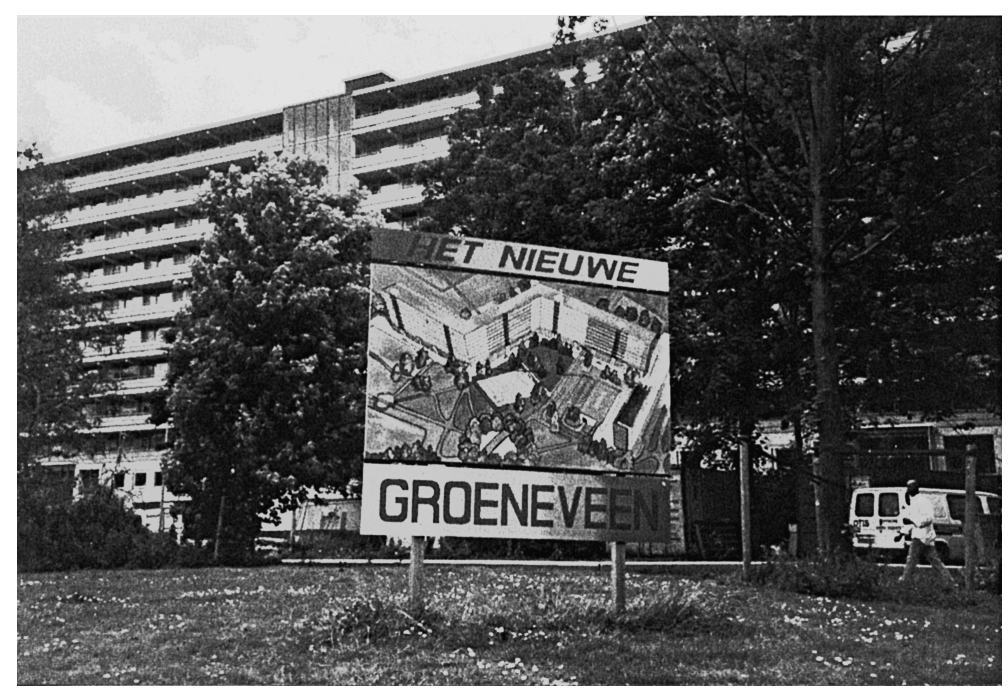

Photo 2. Public relations material (internal promotion) shows the residents how their buildings will look after being refurbished (photo: F. Wassenberg). 


\section{Image as a factor of decline}

A bad image is both a result of and a cause for decay. In the literature on spirals of decay, a deteriorating reputation is often mentioned as an important factor. Skifter Andersen gives an overview. He followed developments in 500 deprived Danish housing estates, in which a bad reputation was mentioned to be the third biggest problem, just after integration of foreigners and technically run-down buildings (Skifter Andersen, 2003). A series of problems causes a stigma, and a stigma worsens the existing problems. Prak and Priemus built a model in 1986 to explain why a process of decay, once it has begun, apparently leads, of its own accord, to further decay. Spirals of physical, social and financial decay intensify each other, thus deepening the process of decay. A decreasing image of the estate is one of the many factors in the model. Heeger elaborates on this model and points at the repeating effect of a negative image: a stigma worsens the already existing problems. He also points to the fact that a stigma of one block of flats can radiate to blocks nearby and even to the whole area (Heeger, 1993, p. 74). In an intensive study of mass housing estates in North-Western Europe, Power (1997) disentangles a range of factors that determine their poor position on the housing market. Starting with unpopular design and management difficulties, they lead to low demand and social stigma, ending up with threat of 'ghetto' conditions. Power emphasises the interrelationship of the distinguished factors.

One of the characteristics of such a spiral of decay is that it is circular. It is hard to point to where the problems start, one of the criticisms of the original model of Park and Priemus. Elsinga and Wassenberg (1991) tried to expand on this point. On the basis of a large survey on crime and flats, they state that a certain sequence of problems can be observed. Causes of decay do not all start at a given moment, but are usually part of a particular sequence. Problems cause new problems, creating a continuous feedback. They place the factor of a decreasing image amidst an ongoing process of decreasing living quality, a process that started after a poor introduction of the estates on the housing market. The main indicator they distinguish is negative publicity.

In Table 3, without pretending to be complete, we list the factors that determine the image of any estate or neighbourhood. We have clustered the factors that the above-mentioned authors refer to and divided these into physical (including technical, environmental, spatial) factors, social aspects (behaviour, characteristics of inhabitants, norms and values, incomes, schooling, integration, etc.), and factors that have to do with 


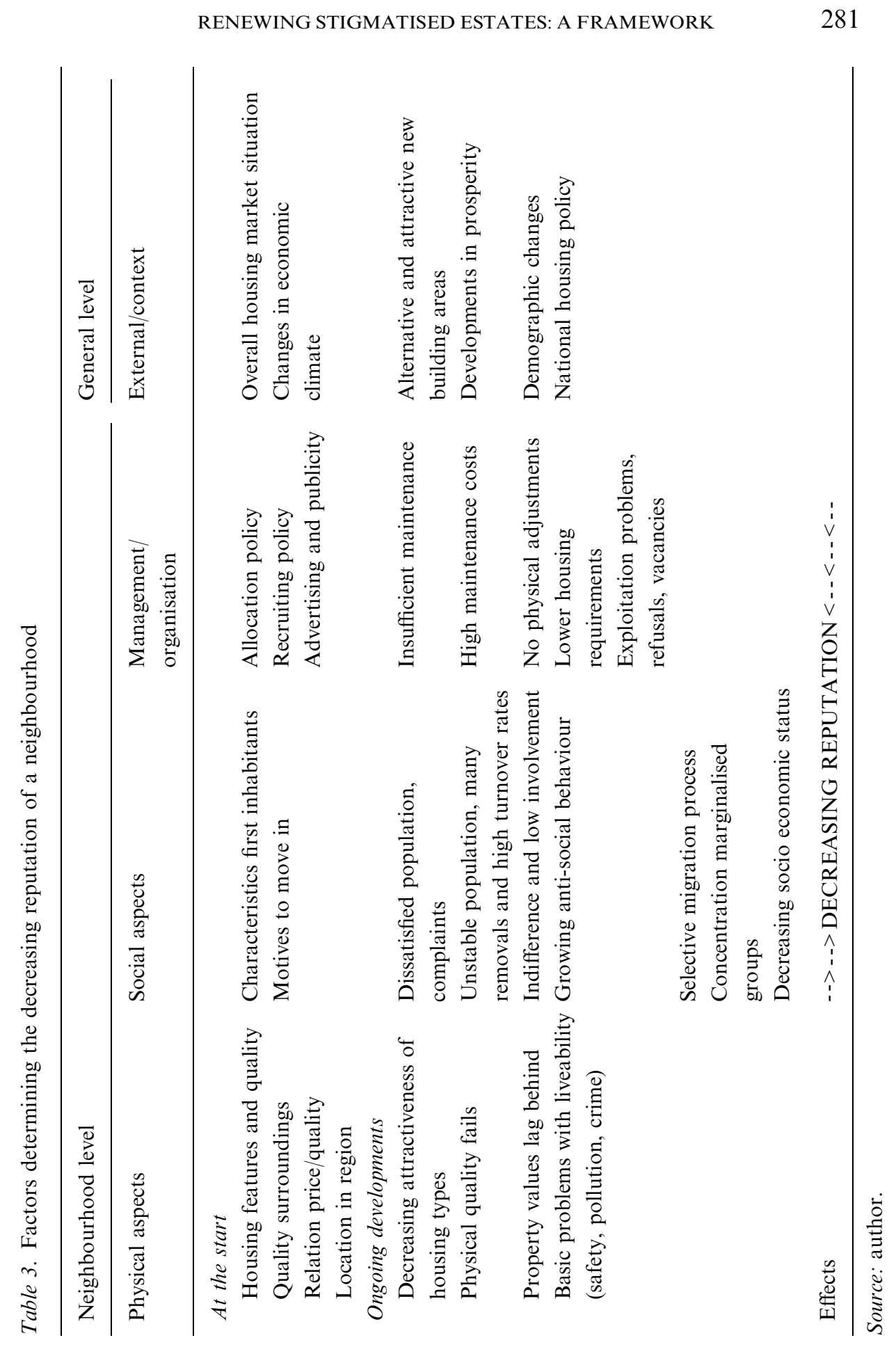


management and organisation. Besides these, there are factors that lie outside the competence of participants dealing with the specific area, like societal developments and national policy-making.

Not all neighbourhoods get off to an equal start. The price/quality ratio may be bad, technical failures may occur, a group of anti-social people can be moved in all together, or the new dwellings may come on the market just at the wrong time. Knol conducted a survey of how the status of 3500 Dutch neighbourhoods has developed during the period 1971-1995. Status was defined as the aggregate of education level, income and (un)employment. He concludes that the changes in status in those 25 years can be explained largely by their position at the start. The most important feature is the type of dwellings, especially the share of owner-occupied dwellings. The more owner-occupied dwellings, the higher the status. A negative and declining status is found most in neighbourhoods in the larger cities, with many small rented flats built in the 1950s and 1960s (Knol, 1998).

After the first year, neighbourhoods develop according to several factors. Both the start and the ongoing developments determine the present image of a neighbourhood. The table includes negative factors that contribute to a declining image of a particular estate. Reputation is an important characteristic to understand the developments and the decay of neighbourhoods. Hortulanus elaborates on the role of reputation, the attractiveness on the housing market and the future expectations of a neighbourhood. He states that when you ask people to rank all neighbourhoods in a list in order of pleasant and attractive places to live, everybody can do it easily. Physical and social aspects play a role. People look at the visible features of the surroundings: the appearance, the built environment, neglect of buildings and the environment and the kind of people living there (Hortulanus, 1999). This is supported by Parkes et al. who conducted a series of studies on neighbourhood satisfaction, They conclude that housing satisfaction and the general appearance of an area were the two main factors related to neighbourhood satisfaction. Renewal should at least include these two elements (Parkes et al., 2002).

\section{Urban renewal in the Netherlands}

Renewal of the image of a neighbourhood is only possible by improving all of the factors that determine that image, as listed in Table 1. Moreover, improving the image is never the main goal; it is a means that 
contributes to the main goal, which is the well-being of an area. A stigma of a problematic area only can be changed by improving the overall living situation in that area. Dean and Hastings (2000, p. viii) conclude that attempts to challenge images will not be effective unless they are grounded in a changed, or at least changing, reality. According to the circumstances, physical, environmental, economic, social, juridical or other measures may be necessary. When the real facts, the problematic liveability, does not improve, both internal and external image-builders will easily see through the policy. As Van Riel states, referring to corporate identity, actual behaviour has a much greater influence on the image than communication and symbols (Van Riel, 1996). The conclusion may be that when an area is problematic, renewal measures are necessary.

Active renewal of decayed areas has been a policy in the Netherlands since the 1970s. The Dutch approach to renovating old neighbourhoods became famous. Cities like Rotterdam, Deventer and (a bit later) Amsterdam were international precursors for renewal projects. The keywords were physical renovation, inexpensive social housing and involvement of inhabitants. The credo was to build for the neighbourhood and promote participation. Renewal of the post-war large estates was not deemed necessary, because these had just been built and were technically adequate. Once the 'classic' renewal process was started, it kept on going, renewing one street after the other, as 'the urban renewal train passing by'.

The present urban renewal policy in the Netherlands was shaped during the 1990s (see an overview in Priemus and Van Kempen (1999)). Urban renewal nowadays is both more complicated and more integral than the relatively easygoing urban renewal of the period 1975-1995. Moreover, instead of old neighbourhoods, renewal now mainly concerns post-war areas, often the large-scale housing estates that are central to this paper. Most renewal plans are made in the Netherlands for low-rise flat areas dating from the 1950s and 1960s, high-rise areas mainly from the period 1965-1974, and areas with austere and simple single-family houses in rows (mainly in smaller towns and villages).

Nowadays, more kinds of measures are carried out, more points of view have to be reckoned with and more participants are involved. Moreover, the role of the population has changed. The present inhabitants have more individual demands, more prosperity and more choice than their parents did 30 years, or more, ago. They ask for more quality and are able to pay for it. This is also clear from experiences with forced relocation due to demolition. Many relocated residents succeed in 
improving their housing situation by moving to better dwellings in the same or other areas (Kleinhans, 2003). People with less choice are doomed to live in the stigmatised areas, to fill up the places people who can afford it will avoid. The present economic recession may expand their numbers, but the main trends are those of prosperity and higher demands, compared with the period when the large housing estates were originally built.

During the years that the Dutch economy did rather well, around the turn of the millennium, change, big plans were made and partly started. At the moment, it is not certain whether there will be sufficient financing to implement these costly plans. Moreover, due to the low volume of building production, the overall housing market has tightened again. The number of vacancies, hard to let dwellings and refusals has dropped, but also the necessity, and the possibility, to renew on a large scale.

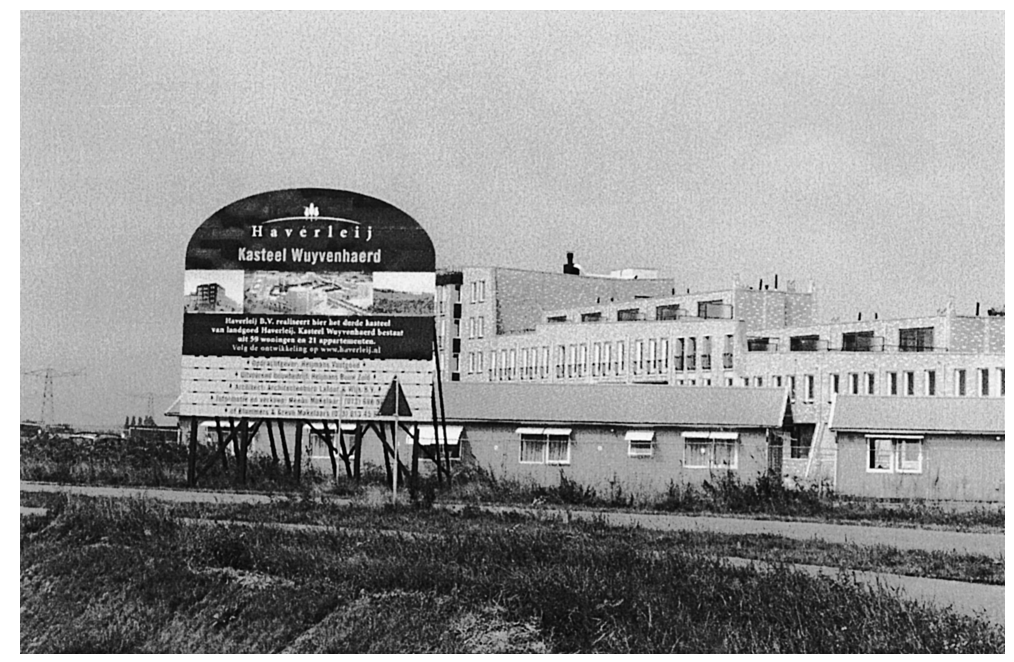

Photo 3. A new housing area is promoted as 'castles on an estate' (photo: F. Wassenberg).

\section{Working on the image of the most stigmatised area in the country: Amsterdam's Bijlmermeer}

Without a doubt, the country's most well known large-scale housing estate is the Bijlmermeer, located in the southeast extension of Amsterdam. High-rise apartment buildings may be found throughout the Netherlands, but nowhere as many as in the Bijlmermeer, with originally 13,000 dwellings in 31 huge blocks. Since the very beginning, 
the Bijlmermeer has continually attracted attention, initially because of its daring and innovative design and later on for its chronic problems. Nowadays, the Bijlmermeer is an example of large-scale renewal. The Bijlmermeer was built between 1968 and 1975 with $90 \%$ high-rise in a mono-functional area dedicated to what was then considered modern living. All modernistic ideas were represented: separation of functions (living, working, recreation), a great deal of space, and park-like landscapes. Traffic flows were separated: pedestrians and cyclists circulate at ground level, while cars drive up above. The planned image of the Bijlmermeer was to develop the neighbourhood of tomorrow for the inhabitants of today. People, middle-class families at first, were expected to stand in line to obtain one of the high-rise flats, eager to escape the dark, narrow and unhealthy slums in the city.

Soon after its completion, its problems began. The dwellings did not correspond to the housing preferences of the intended families, who were more attracted to other cities around Amsterdam where single-family houses with gardens were built. The result was a large number of vacancies, rising to $24 \%$ in 1984 . These flats were allocated to people with less choice on the market, among them many immigrants. Nowadays, only $20 \%$ of the population have Dutch roots. Moreover, there were enormous liveability problems - issues of safety, pollution, nuisance, robberies, degradation, etc., - which the management could not handle. The media found it very easy to confirm the negative image over and over again. The Bijlmermeer was associated with problematic living, not only in the Amsterdam region, but throughout the country and even abroad.

Many solutions were tried. During the early 1980 s, the management was improved, physical improvements were made, public facilities were opened and the high rents were reduced. Furthermore, improvements to the wider area have taken place since the mid-1980s, including a metro line to the city, a large shopping centre, a new football stadium for Ajax, and large cinemas and theatres. Just opposite the railway station, one of the most expensive office areas of the Netherlands was built. In fact, the location of the Bijlmermeer changed from an isolated satellite town into a hot spot (Van Kempen and Wassenberg, 1996). There had been discussions, and trials, about only using the name Amsterdam Southeast instead of Bijlmermeer. One reason this was not done is that the name Bijlmermeer was too well known. Actually, the name of the first refurbished block was indeed changed. The former block 'Gliphoeve' had so many problems in the mid-1970s that a few years after construction it was emptied, renewed and renamed 'Geldershoofd' and 'Gravestein'. 


\subsection{Drastic renewal}

Despite the makeover, the area remained unpopular and the liveability problems were still unsolved. After years of debate, maintenance experiments, adaptations and partial solutions, radical plans were introduced in 1992. A quarter of the area was to be demolished, another quarter sold and the remaining part improved. New types of houses were planned. Besides the physical renewal, socio-economic measures were introduced along with better maintenance to improve liveability. These included job creation, education for adults, stimulation of ethnic entrepreneurship, measures to improve safety, neighbourhood warden schemes, and plans to decrease the uncontrolled public spaces.

A broad evaluation took place in 1999. The question was whether the renewal effort should be intensified. Residents have an important say in these decisions. In 2001 all residents of the remaining blocks were interviewed (Helleman and Wassenberg, 2001). The results were telling: two-thirds were in favour of more demolition, and $60 \%$ were in favour of the demolition of their own house. Demolition gives residents the right to choose another dwelling in the Bijlmermeer or in Amsterdam, and they are given compensation for expenses. In 2002 a final plan was accepted, in which an additional 3000 high-rise flats will be demolished and replaced by the same number of dwellings. All the blocks will be demolished, except for two blocks where residents had other preferences. Besides houses, the plans contain measures for more local businesses and amenities, parking facilities, green areas and water (for more about the Bijlmermeer: see Helleman and Wassenberg, 2004).

The aim of the renewal strategy for the Bijlmermeer is that it should function in a normal way on the Amsterdam housing market, instead of being at the very bottom. The image of the area has to change from inside out. The target groups for new houses are satisfied residents who prefer to live in the Bijlmermeer. Often these are former immigrants, who like the area but not high-rise living. While the internal image has improved, the external image is improving too. It is a slow process, and most Dutch people may still have the same negative image; they may even keep it for the rest of their lives. However, the renewal process takes 16 years in total and is now halfway. When enough progress on the internal image has been made, the external image-building can begin. 


\section{Internal and external strategies for image renewal}

Large housing estates can actually be renewed, but will their image change as well? Image-building can be done for any neighbourhood, which is good, but this in itself is not sufficient when real problems exist. Changing an image of a problem estate without doing anything else is not an option. In practice, the image of a neighbourhood, and especially a negative one, is hardly treated as a factor. Most strategies neglect image building, and when it is considered, it is often a reaction to unexpected events. However, it is possible to treat image-building, and stigma renewal, as an active programme and as a part of an overall renewal approach. Images of neighbourhoods can be actively promoted, just as in the commercial sector, where all kinds of products are being promoted.

\subsection{A framework for image renewal strategies}

Image-promoting activities can be directed at both the internal and the external participants, as noted earlier. In Section 4 we introduced a framework to position neighbourhoods according to images of the internal and the external participants. In Table 4 we fill out this framework with strategies for image renewal. It is interesting to see in which of the four corners of the scheme a neighbourhood is positioned. This makes it useful to differentiate between several image promotion activities. Is image promotion aimed at internal or external participants? Which measures are adequate? Which problems are tackled or focused on? And what are the targets?

Table 4 gives an overview of the different roles that image renewal through public relations may have. In both of the opposite corners (1) and (4), image renewal activities can be rather small scale, but for opposite reasons. In corner (1) many neighbourhoods are positioned where people just live their lives, while very problematic areas can be placed in corner (4) where drastic measures are necessary instead of extra promotion of the area. On the contrary, inhabitants and outsiders will probably see through this 'window dressing' when real improvements do not materialise. The policy for such an area only can be one of severe intervention. Just some physical renewal, just some better maintenance or just some schooling or work programmes will not be enough. This is not to say that just an image improvement campaign won't make any sense there at all. 


\subsection{Image renewal of unknown qualified neighbourhoods}

In the corners (2) and (3) image renewal can be an important part of a renewal process. However, the accent fundamentally differs. In corner (2) are neighbourhoods where inhabitants are rather satisfied, but outsiders do not see that. Image promotion can sell the area to the wider public, making the area itself known as well as the advantages of living there. Making the area known may be the motto. Public relation should be aimed mainly at external parties. Some possible strategic activities for neighbourhoods positioned in this corner are:

- Create new landmarks or renew a central part in the area, promote it as a landmark and use it as a platform for further projects.

- Create major events to gain external attention.

- Consistently give all positive events in an area wider publicity.

- Seek contacts with relevant journalists and get to know them personally. Explain and show them the considerations behind any policy.

- Work on an identity of their own for 'grey and superficial' neighbourhoods.

Table 4. Strategies for image renewal of neighbourhoods

\begin{tabular}{|c|c|c|c|}
\hline \multirow[t]{2}{*}{ Image } & & \multicolumn{2}{|l|}{ External image } \\
\hline & & Good & $\mathrm{Bad}$ \\
\hline $\begin{array}{l}\text { Internal } \\
\text { Image }\end{array}$ & Good & $\begin{array}{l}\text { (1) (nice neighbourhoods) } \\
\text { No special strategy is necessary } \\
\text { The image is okay } \\
\text { p.r. can be small scale } \\
\text { (3) (unsatisfactory } \\
\text { neighbourhoods) } \\
\text { Visible improvements in the } \\
\text { area p.r. directed to inhabitants } \\
\text { Show progress Internal p.r. }\end{array}$ & $\begin{array}{l}\text { (2) (unknown qualified } \\
\text { neighbourhoods) } \\
\text { Image promotion } \\
\text { Accent on 'selling advantages } \\
\text { of the area' Active } \\
\text { involvement of the media } \\
\text { Accent on external p.r. } \\
\text { (4) (problematic } \\
\text { neighbourhoods) } \\
\text { Image renewal is following } \\
\text { concrete results Priority to } \\
\text { intensive integral renewal } \\
\text { p.r. can be small scale, } \\
\text { awaiting results }\end{array}$ \\
\hline
\end{tabular}


The last item deserves some explanation, which is called 'branding of neighbourhoods'. This is a marketing tool to clarify a product's identity with the aim of giving it a clear position on the market. The product is the neighbourhood; the marketers are trying to create a characteristic identity, to distinguish it from other areas. There is a discussion going on in the Netherlands on whether a new identity can be created from the top down by using marketing techniques. Reinders (forthcoming), after Raban (1974), differentiates between the 'hard' city as developed by architects, planners and politicians and the 'soft' city as experienced years later by the users, who are often the inhabitants. The large-scale areas, which this paper is all about, experience big differences between hard and soft, between the nice planning ideals and the blunt truth that emerges afterwards.

\subsection{Image renewal of unsatisfactory neighbourhoods}

In corner (3) the public image is reasonable, though the inhabitants themselves voice complaints. In a situation like this, a start should be made on improving the liveability situation. Often minor improvements can help. Image promotion should emphasise the present inhabitants, to give a better picture of the positive things that are taking place in the area, and to show that actual improvements are being made. External promotion could be small in scale. Some possible strategic activities for these neighbourhoods are the following:

- Create positive events. Organise them or stimulate groups to make them to happen. Budgets for a sporting tournament, a neighbourhood party, a barbecue, are peanuts compared to costly renewal or maintenance expenses.

- Tackle the inconveniences; people do not complain for no reason.

- Consistently give all positive events in an area local publicity.

- Intensify contacts with relevant journalists and get to know them personally. Explain and show them the considerations behind any policy. Show them both good things and bad.

- Cherish the committed residents in the area, who endure the problems. Protect them and help them, for example, by taking steps against notorious troublemakers. Be clear about values and rules.

- Support positive initiatives and make these known to all inhabitants, including the potential leavers. 


\subsection{Long process}

Even when the actual situation is being improved, a stigma can last for many years, maybe even a lifetime. Moreover, it takes a long time to improve a stigma once set, if possible at all. Buys (1997) and Dean and Hastings (2000) point out the difficulty of improving the perceived image of a stigmatised area. Along with that, they note the difficulty of improving the neighbourhood hierarchy position, even when a large renewal programme is taking place. However, there are some more optimistic reports. The case of the Bijlmermeer shows that first the internal and later on the external image are changing, but it is a slow and long-lasting process. In a Danish evaluation of the renewal of 500 deprived estates, $55 \%$ of the estates found that problems of a bad reputation were reduced, while only a few have deteriorated (Skifter Andersen, 2003). However, this research was conducted only shortly after the actual renewal activities. It would be good to explore effects in the longer term.

The conclusion might be that image renewal takes a long time, and sometimes it is easier to change the area itself than to change its image. Image-promoting can be a way to make progress, at least to some extent, in this complicated process.

\section{Conclusions}

Image-building and stigmatising of neighbourhoods do not get much explicit attention in the literature. This is remarkable, because in case studies concerning problematic housing estates, the image factor always is mentioned in connection with the process of decay. A stigma, defined as a bad image or reputation, is both a result and a cause for further decay. It is determined by a series of related factors that often occur in a certain sequence.

Images differ per person or groups of persons. Image-building can refer to internal or external images. Image building is a mental process for both internal and external groups. A stigma can be associated with the appearance of an area, or simply with its name. Neighbourhood types are associated with status; this is accompanied by an image and a position in the personal housing or neighbourhood hierarchy. It is interesting that the most frequently reviewed and well - thought-out large housing estates are probably the areas with the worst images.

Renewal of the image of a problematic neighbourhood is only possible if tackled along with actual improvements. This means a 
combination of physical, environmental, social, economic and organisational measures, according to the local circumstances. Images of neighbourhoods can be actively promoted, just like a commercial product. Image promotion is one of the possible measures which is seldom used in renewal processes. It depends on local circumstances which strategy should be the best, but strategies should be aimed at the existing internal and external images. In areas where the external image exceeds the internal image and inhabitants complain about unsatisfactory living conditions, image promotion may be best directed to internal participants to convince them the situation really is improving. In neighbourhoods that are hardly known by outsiders, public relations could be directed to external participants, to promote the area and to counterbalance prejudices. It is important to analyse first in which local situation a neighbourhood is seen by internal and external actors.

Image promotion may be an important strategy, but the actual situation will be more important for both the internal participants like the inhabitants and the external participants like possible incomers. Changing the stigma of large housing estates is a process that takes a very long time, as shown by the case of the Amsterdam Bijlmermeer. It may be easier to change the whole neighbourhood than to change its image, at least its external image. It takes a long time to improve a stigma once set. Despite these limitations, it is very useful to work on a stigma and to give active image promotion explicit attention in any renewal process.

\section{References}

Buys, A. (1997) De ideale mix [A Study to Population mix in Neighbourhoods], RIGO, Amsterdam.

Commissie Hoogbouw-Laagbouw (1961) Laag of hoog Bouwen en Wonen [High or Low Building and Living], Samsom, Alphen aan den Rijn.

Dean, J. and Hastings, A. (2000) Challenging Images, Housing Estates, Stigma and Regeneration, The Policy press, Bristol.

Elsinga, M. and Wassenberg, F. (1991) Tackling Crime and Vandalism on Post-war Housing estates: The Dutch Approach, Netherlands Journal of Housing and the Built Environment, 6(2), 159-175.

Heeger, H. (1993) Aanpak Van naoorlogse Probleemcomplexen [Approaches to Postwar Problematic Housing Estates], DUP, Delft.

Helleman, G. and Wassenberg, F. (2001) Bewonersonderzoek Finale Plan van Aanpak Bijlmermeer [Residents Survey Final Plan of Approach Bijlmermeer], DUP Satellite, Delft.

Helleman, G. and Wassenberg, F. (2004) The Renewal of what was Tomorrow's Idealistic city. Amsterdam's Bijlmermeer high-rise, Cities, 21(1), 3-17. 
Hortulanus, R. (1995) Stadsbuurten [City Neighbourhoods], VUGA, The Hague.

Hortulanus, R. (1999) Het beeld van de buurt [the image of an area], In: De gedroomde wijk [The Dreamed Neighbourhood], Forum, Utrecht.

Van Kempen, R. and Wassenberg, F. (1996) Trouble in High-rise Paradise, Amsterdam's Bijlmermeer, Geografie, 5(5), 20-23.

Kleinhans, R.J. (2003) Displaced but still Moving Upwards in the Housing Career? Implications of Forced Residential Relocation in The Netherlands, Housing Studies, 18(4), 473-499.

Knol, F.A. (1998) Van Hoog naar laag; van laag naar hoog: de Sociaal-Ruimtelijke Ontwikkeling van Wijken Tussen 1971-1995 [A Study on Socio-economic Development in Neighbourhoods], Cahier 152, SCP, Den Haag.

Mentzel, M. (1990) The Birth of Bijlmermeer, 1965: The Origin and Explanation of High-rise Decision Making, Netherlands Journal of Housing and Environment Resarch, 5(4), 359-375.

Nauta, O., Tulner, H. and van Soomeren, P. (2001) De Bijlmer Monitor 2000, Van Dijk, Van Soomeren en partners, Amsterdam.

Nelissen, N.J.M. et al. (1976) Verval in buurten. Theoretische Beschouwing en Concreet Onderzoek in de Rivierenwijk-West [A Theoretical Consideration and a Case Study on the Decay of Neighbourhoods], Nijmegen.

Parkes, A., Kearns, A. and Atkinson, R. (2002) What makes people dissatisfied with their Neighbourhoods?, Urban Studies, 39(13), 2413-2438.

Priemus, H. and Van Kempen, R. (1999) Restructuring Urban Neighbourhoods in the Netherlands: Four Birds with One Stone, Netherlands Journal of the Built Environment, 14(4), 403-412.

Power, A. (1997) Estates on the Edge: The Social Consequences of Mass Housing in Northern Europe, Macmillan Press, London.

Prak, N.L. and Priemus, H. (1986) A Model for the Analysis of the Decline of Post-war Housing, International Journal of Urban and Regional Research, 10(1), 1-17.

Raban, J. (1974) Soft City, Fontana/Collins, Glasgow.

Reinders, L. (forthcoming) Local, Global, Glocal: Place and Identity in a Parisian Banlieue, In: Ed., Eckard, F. Urbanism and Globalization.

Skifter Andersen, H. (2003) Urban Sores; on the Interaction between Segregation, Urban Decay and Deprived Neighbourhoods, Ashgate, Hants (UK)/Burlington (USA).

Turkington, R., Van Kempen, R. and Wassenberg, F. (2004) High-rise Housing in Europe, Current Trends and Future Prospects (HUPS 28), Delft University Press, Delft.

Van Riel, C.B.M. (1996) Identiteit en imago, Grondslagen voor Corporate Communication [Identity and Image, Basis for Corporate Communication], Academic Service, Schoonhoven. 